\title{
Psidium cattleianum (Myrtaceae) as a Natural Antimicrobial Source Against Oral Bacteria
}

\author{
Marcelle Marie Buso-Ramos*, Simone Nataly Busato de Feiria, Giovana Cláudia Boni and José Francisco \\ Höfling \\ ${ }^{1}$ Department of Oral Diagnosis, University of Campinas, Brazil
}

Submission: April 21, 2017; Published: May 12, 2017

*Corresponding author: Marcelle Marie Buso-Ramos, Department of Oral Diagnosis, University of Campinas, Brazil, Tel/Fax: +55 (19) 2106-5322;

Email: marcellebuso@gmail.com

\begin{abstract}
Psidium cattleianum or strawberry guava is a common tropical plant in Brazil belonging to Myrtaceae family. However, this plant is an underexploited source of medicinal compounds, evidenced by photochemical investigations that describe, in recent reports, its antioxidant, antiproliferative and antimicrobial actions. In this mini review, the antimicrobial prospect of the extract and the essential oil from $P$. cattleianum leaves against oral bacteria will be discussed. It is believed that, this review will serve as a useful reference and encourage future research about antimicrobial potential of this plant against oral microorganisms.
\end{abstract}

Keywords: Psidium cattleianum; Antimicrobial; Oral bacteria

Abbreviations: MIC: Minimum Inhibitory Concentration; LD50: Lethal Dose 50; GTF: Glicosiltranferases; EPS: Extracellular Polysaccharide

\section{Introduction}

Investigation of natural compounds from popular medicinal plants have advanced in the last decades in the attempt to characterize scientifically the possible beneficial effects and side effects, as well as the determination of a safe dose of use [1]. Among the families of medicinal plants, the Myrtaceae family stands out, whose genus Psidium adds fruit species such as Psidium guajava, the popular guava. However, the species Psidium cattleianum and its variants, known as strawberry guava, has been studied in the last decades because of its medicinal property such as analgesic effects [2], antioxidant [3,4], anti-proliferative action [4], anticancer [4] and antimicrobial agent [5]. In popular medicine, $P$. cattleianum is known for its action against diabetes, tummy aches, urinary tract diseases and diarrhea, where it is recommended to use shoots, leaves and bark of the trunk [6].

\section{P. cattleianum Medicinal Compounds}

The medicinal effects are derived from the bioactive compounds in plants that originate from the secondary metabolism, which is not involved in the essential metabolic pathways for plant's life, but play the role of defense in plants against bacteria, fungi, viruses, environmental stress, Herbivorous attack and attraction of pollinating agents [7]. The phenolic compounds are found in plants extracts and showed antimicrobial activity by causing degradation in bacterial cell wall, damage in cytoplasm membrane and consequent cellular material extravasation, cytoplasm coagulation and disruption in the ion/electrons membrane transport system. Any disarrangement on the cellular surface entails in ruptures in cell surface, which leads the output of vital cellular components and entry of harmful in bacterial cell [8].

Terpenoid compounds are found in essential oils. Monoterpenes and sesquiterpenes are the most abundant terpenoids compounds and play an antimicrobial action involving membrane fluidification, destabilization of membrane binding proteins involved in signaling and anchorage, rest of cell cycle and induction of apoptosis in Candida albicans cells [9]. Turina et al. [10] reported that owing the high hydrophobicity of monoterpenes, their toxic effects on the bacterial cell membrane result in its expansion, fluidity, and permeability, in addition to causing inhibition of respiration and change in the process of ions transport, but further studies should be conducted to characterize in detail these mechanisms. In the work of [11], the Brazilian $P$. cattleianum plant showed by GC/MS 33 components corresponding to $96.9 \%$ of the oil, and the main terpenoids of the essential oil were $\alpha$-thujene (25.2\%), followed by 1,8-cineole $(16.4 \%)$ and $\beta$-caryophyllene $(10.2 \%)$. This results were similar to the African P. cattleianum plant, that were identified by CG/ MS a total of 53 chemical components, accounting for $61 \%$ of the essential oil and the major component was caryophyllene 
oxide (12.43\%), bicyclo(4.4.0)dec-l-ene (6.61\%), 2,3-butanediol diacetate $(4.84 \%)$ and patchoulene $(4.73 \%)$. The presence of many terpenic and ester compounds is thought to contribute to the unique flavor of the P. cattleianum leaves [12]. In the aqueous extract of $P$. cattleianum the phenolic compounds present were: 3 flavonoids (kaempferol, quercetin, and cyanidin) and 1 is a tannin (ellagic acid) [5]. Although, the oil and extract compounds of $P$. cattleianum leaves may vary in response to different physical, atmospheric, growth region and time of year collections.

\section{Antimicrobial Effects of Essencial Oil and Extracts from $P$. Cattleianum Leaves}

Scur et al. [13], testing the antimicrobial activity of Psidium cattleianum essential oil, (prepared with metanol) showed a high minimum inhibitory concentration (MIC) of $200 \mathrm{mg} / \mathrm{ml}$ for grampositive microorganisms (E. faecalis, S. epidermidis, S. aureus, $B$. subtillis and C. albicans) and for gram-negative microorganisms (P. aeruginosa, S. enteritidis, P. mirabilis, K. pneumonia and E.coli). Although, comparative studies involving the essential oil of leaves of $P$. cattleianum are still in scarce and its antimicrobial effects are undescribed and uncharacterized. The extract of $P$. cattleianum produced with ethyl acetate showed MIC of $125 \mathrm{ug} / \mathrm{ml}$ against S.aureus while the methanol extract showed an MIC of 250ug/ $\mathrm{mL}$, but both extracts types had no effect against gram-negative microorganisms [14]. However, Gaetti-Jardim et al. [15] tested the antimicrobial action of aqueous and hydro alcoholic extracts from $P$. cattleianum leaves against gram-negative microorganisms (F. nucleatum and P. gingivalis) showed MICs of $2 \mathrm{mg} / \mathrm{mL}$ in both extracts with a reduction of $50 \%$ in bacterial growth and $8 \mathrm{mg} / \mathrm{mL}$ for aqueous and hydro alcoholic extracts with a reduction of $90 \%$ in bacterial growth. These different results may be related to the different extractive methods and the solvent used in the process employed by the authors, which may have influenced in isolating bioactive compounds of plant and determination of properties [16].

Brighenti et al. [17] evaluated the leaves aqueous extract of $P$. cattleianum on the biofilm of Streptococcus, showed that biofilms exposed to the extract effects at $1.6 \%(\mathrm{v} / \mathrm{v})$ for $2 \mathrm{~h}$ were shown to decrease in $S$. mutans proteins from carbohydrate metabolism and a reduction in $\mathrm{pH}$ drop after exposure to the extract. The decrease in extracellular polysaccharide (EPS) formation observed after sucrose application may also be related to the inhibition of glicosiltranferases (GTF) activity in dental biofilms, which reduce de biofilm resistance of $S$. mutans.

Menezes et al. [18] also studied and corroborated that the aqueous extract of $P$. cattleianum significantly reduced the $S$. mutans count and decreased the enamel demineralization rate in rats, characterizing an anti-carie activity. Brighenti et al. [5], evaluating the anti-caries effect of $P$. cattleianum leaf extract using an "in situ" caries model found that $P$. cattleianum leaf extract might reduce enamel demineralization, acidogenic potential, microorganism viability and extracellular polysaccharide production. Having clearly demonstrated the potential activity of $P$. cattleianum leaf extract to interfere in "in situ" biofilm pathogenicity, the effect of this plant extract on biofilm formation "in vivo" should be evaluated in the future.

\section{Toxicity of $P$. cattleianum}

The low toxicity of Psidium spp. extract is described in the literature. The LD50 of $P$. guajava leaf extract is more than $5 \mathrm{~g}$ $\operatorname{kg}\urcorner$-. Teixeira et al. [19] demonstrated that P. guajava infusion does not alter chromosomes or the cell cycle both in vitro and in vivo. Costa et al. [20] show that $P$. cattleianum leaf extract does not have any genotoxic or mutagenic effects on some cell types of mice, suggesting that this extract can be used as a safe therapeutic agent. The crude ethanolic extract of the plant was obtained through maceration and fractionated with hexane, dichloromethane, and ethyl acetate for test in microcrustacean Artemia salina for toxicological assessment. Regarding toxicity, hexane and dichloromethane fractions were considered nontoxic, whereas the crude ethanol extract and the ethyl acetate fraction showed low toxicity [4]. There is no data in literature about $P$. cattleianum essential oil toxicity.

\section{Conclusion}

Extracts and essential oil from Psidium cattleianum leaves has antimicrobial properties against oral microorganisms, presenting absence or low toxicity and cytotoxicity in eukaryotic cells. Studies with $P$. cattleianum essential oils and extracts that characterize medicinal effects and its photo chemical composition should be encouraged for propose future alternatives to combat infections, control microorganisms growth and promote surfaces treatment against biofilms development with the aim that, in the future, can be applied in health area in an economically viable way.

\section{References}

1. Bakkali FS, Averbeck S, Averbeck D, Idaomar M (2008) Biological effects of essential oils - A review. Food and Chemical Toxicology 46(2): 446-475.

2. Alvarenga FQ Mota BC, Leite MN, Fonseca JM, Oliveira DA, et al. (2013) In vivo analgesic activity, toxicity and phytochemical screening of the hydroalcoholic extract from the leaves of Psidium cattleianum Sabine. J Ethnopharmacol 150(1): 280-284.

3. Medina AL, Haas LIR, Chaves FC, Salvador M, Zambiazi RC, et al. (2011) Araçá (Psidium cattleianum Sabine) fruit extracts with antioxidant and antimicrobial activities and anti-proliferative effect on human cancer cells. Food Chem 128(4): 916-922.

4. Faleiro JH, Gonçalves RC, Santos MNG, Silva DP, Naves PLFN, et al. (2016) The Chemical Featuring, Toxicity, and Antimicrobial Activity of Psidium cattleianum (Myrtaceae) Leaves. New Journal of Science 1-8.

5. Brighenti FL, Gaetti-Jardim E, Danelon M, Evangelista GV, Delbem AC (2012) Effect of Psidium cattleianum leaf extract on enamel demineralisation and dental biofilm composition in situ. Arch Oral Biol 57(8): 1034-1040.

6. Boscolo OH, Senna Valle L (2008) Plantas de uso medicinal em Quissamã, Rio de Janeiro, Brasil. IHERINGIA, Série Botânica 63(2): 263-277.

7. Müller NTG, Fasolo D, Bertê R, Ely CV, Holz DT (2012) Análise Fitoquímica das Folhas de Myrtaceae: Psidium cattleianum Sabine e Campomanesia guazumaefolia (CAMB.) Berg. Vivências 8(14): 65-71. 
8. Burt S (2004) Essential oils: theirs antibacterial properties and potencial applications in foods a review. International Jounal of Microbiology 94(3): 223-253.

9. Zore GB, Thakre AD, Jadhav S, Karuppayil SM (2011) Terpenoids inhibit Candida albicans growth by affecting membrane integrity and arrest of cell cycle. Phytomedicine 18(13): 1181-1190.

10. Turina AV, Nolan MV, Zygadlo JA, Perillo MA (2006) Natural terpenes: self-assembly and membrane partitioning. Biophysical Chemistry 122(2): 101-113.

11. Marques FA, Wendler EP, Maia BHLN, Coffani-Nunes JV, Campana J, et al. (2011) Volatile oil of Psidium cattleianum Sabine from brazilian atlantic forest. Journal of Essential Oil Research 20(6): 519-520.

12. Chalannavar RK, Narayanaswamy VK, Baijnath H, Odhav B (2012) Chemical composition of essential oil of Psidium cattleianum var lucidum (Myrtaceae) African Journal of Biotechnology 11(33): 83418347.

13. Scur MC, Pinto FGS, Pandini JA, Costa WF, Leite CW, et al. (2016) Antimicrobial and antioxidant activity of essential oil and different plant extracts of Psidium cattleianum Sabine. Braz J Biol 76(1): 101108

14. Desoti VC, Maldaner CL, Carletto MS, Heinz AA, Coelho MS, et al. (2011) Triagem fitoquímica e avaliação das atividades antimicrobiana e citotóxica de plantas medicinais nativas da região oeste do estado do Paraná. Arquivos de Ciências da Saúde 5(1): 3-13.
15. Gaetti-Jardim E, Landucci LF, Arafat OKK, Ranieri RV, Ramos MMB, et al. (2011) Antimicrobial activity of six plant extracts from the brazilian savanna on periodontal pathogens. Int J Odontostomat 5(3): 249-256.

16. Koba K, Matsouka A, Osada K, Huang Y (2007) Effect of loquat (Eriobotrya japonica) extracts on LDL oxidation. Food Chemistry 104(1): 308-316.

17. Brighenti FL, Luppens SBI, Delbem ACB, Deng DM, Hoogenkamp MA et al. (2008) Effect of Psidium cattleianum leaf extract on Streptococcus mutans viability, protein expression and acid production. Caries Res 42: 148-154.

18. Menezes TEC, Delbem ACB, Brighenti FL, Okamoto AC, Gaetti-Jardim E (2010) Protective efficacy of Psidium cattleianum (Sabine) and Myracrodruon urundeuva (Allemao) leaf extracts against caries development in rats. Pharm Biol 48: 300-305

19. Teixeira RO, Camparoto ML, Mantovani MS, Vicentini VEP (2003) Assessment of two medicinal plants, Psidium guajava L. and Achillea millefolium L., in vitro and in vivo assays. Genet Mol Biol 26(4): 551555.

20. Costa TD, Vieira S, Andrade SF, Maistro EL (2008) Absence of mutagenicity effects of Psidium cattleyanum Sabine (Myrtaceae) extract on peripheral blood and bone marrow cells of mice. Genet Mol Res 7(3): 679-686.
This work is licensed under Creative Commons Attribution 4.0 Licens DOI: 10.19080/ADOH.2017.04.555650 